\title{
Meta-Analysis the Effect of Malaria Infection on Anemia in Pregnant Women
}

\author{
Firdausi Nuzula'), Setyo Sri Rahardjo²), Bhisma Murti1) \\ ${ }^{1)}$ Masters Program in Public, Universitas Sebelas Maret \\ 2)Faculty of Medicine, Universitas Sebelas Maret
}

\section{ABSTRACT}

Background: Malaria is an important threat to pregnant women, with an increased risk for both mother and newborn, especially in the first and second pregnancies caused by $P$. falciparum. Malaria infection in pregnant women can cause anemia in the mother and fetus, as well as babies with low birth weight, this can increase maternal and infant mortality rates. This study aims to analyze the magnitude of the influence of malaria infection in pregnant women on the incidence of anemia based on a number of previous similar studies.

Subjects and Method: This was a systematic review and meta-analysis carried out by following the PRISMA flow diagram. The process of searching for articles is carried out through a journal database which includes: Google Scholar, PubMed, and Science Direct by selecting articles published in 2010-2020. Key words used include: "malaria infection" AND "pregnancy women" OR "anemia" AND "adjusted odds ratio". The inclusion criteria were full paper articles with observational study design, articles in English, multivariate analysis used with adjusted odds ratios. Articles that meet the requirements are analyzed using the Revmen 5.3 application.

Results: A total of seven articles were reviewed in this study with a cross-sectional study design. A meta-analysis of 7 cross-sectional studies showed that malaria infection had a 1.72 times increased risk of anemia in pregnant women compared to those not infected with malaria (aOR 1.72; 95\% CI 1.43 to 2.07; $\mathrm{p}<0.001$ ).

Conclusion: Malaria infection increases the risk of anemia in pregnant women.

Keywords: malaria infection, pregnancy, anemia, meta-analysis

\section{Correspondence:}

Firdausi Nuzula. Masters Program in Public Health, Universitas Sebelas Maret. Jl. Ir. Sutami 36A, Surakarta 57126, Central Java. Email: ulafn10@gmail.com.

\section{Cite this as:}

Nuzula F, Rahardjo SS, Murti B (2020). Meta-Analysis the Effect of Malaria Infection on Anemia in Pregnant Women. J Epidemiol Public Health. 05(04): 489-498. https://doi.org/10.26911/jepublichealth.2020.05.04.11.

\section{BACKGROUND}

Globally, more than 200 million cases of malaria occur each year with an estimated half a million deaths. Malaria is an important threat to pregnant women, with an increased risk for both mother and newborn, especially in the first and second pregnancies caused by $\mathrm{P}$. falciparum. Risks that occur include fetal death, prematurity, low birth weight, and severe maternal anemia (Corrêa et al., 2017).
Eleven million pregnant women who were exposed to malaria infection in 2019 gave birth to around 872 thousand children with low birth weight. $16 \%$ of all low birth weight children are in African countries (World Health Organization, 2019). The number of malaria cases in pregnant women in Indonesia in 2019 was 1,769. Most cases were reported from Papua province, when compared to the number of malaria cases, the proportion of malaria in 
pregnant women was $0.5 \%$. The highest number of pregnant women who were screened for malaria was reported from the Province of East Nusa Tenggara as much as 61,065 , while the total number of screening for pregnant women in 2018 was 355,956 (Indonesian Ministry of Health, 2019).

Malaria is a serious and fatal disease caused by parasites that usually infect certain types of mosquitoes that feed on human blood. People with malaria usually have a high fever, chills, and a flu-like illness (CDC, 2020).

Anemia is characterized by a decrease in the number of red blood cells in the blood (or a decrease in the concentration of hemoglobin [Hb]) to a level that interferes with the normal physiological capacity of the blood to carry oxygen to cells throughout the body. The World Health Organization (WHO) defines mild anemia as an $\mathrm{Hb}$ concentration between $10 \mathrm{~g} / \mathrm{dL}$ and $10.9 \mathrm{~g} /$ $\mathrm{dL}$, moderate anemia between $7 \mathrm{~g} / \mathrm{dL}$ and $9.9 \mathrm{~g} / \mathrm{dL}$, and severe anemia below $7 \mathrm{~g} / \mathrm{dL}$. Iron deficiency is considered to be the most common cause of anemia (World Health Organization, 2019).

Infected and not infected by the spleen, and impaired production of red blood cells by the bone marrow. People who suffer from anemia have a greater risk of death, including from malaria. Exposure to malaria infection during pregnancy causes maternal anemia, which is associated with a higher risk of obstetric bleeding and death (World Health Organization, 2019). Malaria infection in pregnant women can cause anemia in the mother and fetus, as well as babies with low birth weight, this can increase maternal and infant mortality rates. Complications of malaria infection in pregnancy can include abortion, babies with low birth weight, anemia, pulmonary edema (swelling or accumulation of fluid in the lung tissue), impaired kidney function, and congenital malaria (Budiyanto and Wuriastuti, 2017).

Malaria in pregnancy, even without symptoms, is associated with adverse effects on pregnant women as well as the fetus. Falciparum malaria was a risk factor for severe anemia $(\mathrm{OR}=2.8 ; 95 \% \mathrm{CI}=2.1$ to 3.7), while vivax malaria was associated with moderate anemia $(\mathrm{OR}=1.5 ; 95 \% \mathrm{CI}=$ 1.1 to 2.0) (Wabula et al., 2014).

Meta-analysis is an epidemiological study that combines and statistically combines the results of a number of independent primary studies that are considered combinable, testing the same hypothesis in the same way, so that a quantitative overview is obtained. Meta-analysis is an inseparable part of a systematic study because no meta-analysis is carried out without first systematically reviewing various studies whose findings are summarized quantitatively (Murti, 2018).

Based on this background, a comprehensive study from various primary studies on the effect of malaria infection in pregnant women is needed on the incidence of anemia. The data obtained will be analyzed using a systematic review and meta-analysis by conducting a synthesis of the results of studies conducted to reduce bias.

\section{SUBJECTS AND METHOD}

\section{Study Design}

This was a systematic review and metaanalysis. The articles used in this study were obtained from several databases including Google Scholar, PubMed, and Science Direct. The keywords to find the article were as follows: "malaria infection" AND "pregnancy women" OR "anemia" AND "adjusted odds ratio".

\section{Inclusion Criteria}

The inclusion criteria for articles that could be reviewed were full paper articles with observational study design, articles in 
English, multivariate analysis used with adjusted odds ratios, the intervention given was having a history of malaria infection during pregnancy. The research subjects were pregnant women and the outcome was anemia.

\section{Exclusion Criteria}

The articles published in this study are articles that have been carried out by metaanalysis. Articles are published other than in English. Articles are those with results not adjusted Odds Ratio.

\section{Operational Definition}

The article search was carried out by considering the eligibility criteria defined using the PICO model. The population in the study were pregnant women with intervention in the form of malaria infection, the comparison was no malaria infection and the outcome was anemia.

Anemia in pregnancy is a hemoglobin level below $11 \mathrm{~g} \%$ in the first and third trimesters or a level below $10.5 \mathrm{~g} \%$ in the second trimester. The instrument used was a check for hemoglobin levels.

Malaria infection is a specific condition in pregnant women and is characterized by the accumulation of red blood cells containing the malaria parasite. The instruments used were the results of microscopic examination, RDT, PCR.

\section{Data Analysis}

Data processing was carried out by the Review Manager (RevMan 5.3) by calculating the effect size and heterogeneity to determine the research model that was combined and formed the final metaanalysis result.

\section{RESULTS}

The process of searching for articles by searching through the database according to PRISMA, the flow diagram can be seen in Figure 1.

Research related to the effect of malaria infection in pregnant women on the incidence of anemia consisted of 7 articles from the initial search process yielding 1289 articles. It can be seen in Figure 2 that the research articles came from 2 continents, namely Africa (Ethiopia, Sudan, Ghana, Nigeria, Tanzania) and America (Columbia). Furthermore, in Table 1 the researchers conducted an assessment of the quality of the articles. Table 3 shows that there are 7 articles of cross-sectional studies as evidence of the association of the effect of malaria infection in pregnant women on the incidence of anemia.

Based on the forest plot results (Figure 3) in a cross-sectional study, it shows that malaria infection can increase the incidence of anemia in pregnant women by 1.72 times compared to those who are not infected with malaria (aOR 1.72; 95\% CI 1.43 to $2.07 ; \mathrm{p}<0.001)$. The heterogeneity of the research data shows I $2=49 \%$ so that the distribution of the data is stated to be homogeneous (fixed effect model).

The funnel plot (Figure 4) shows a publication bias which is characterized by asymmetry of the right and left plots, 2 plots on the left and 5 plots on the right. The plot on the left has a standard error between 0.2 and 0.5 and the plot on the right has a standard error between 0.1 and 0.4 . 
Nuzula et al./ Meta-Analysis the Effect of Malaria Infection on Anemia in Pregnant Women

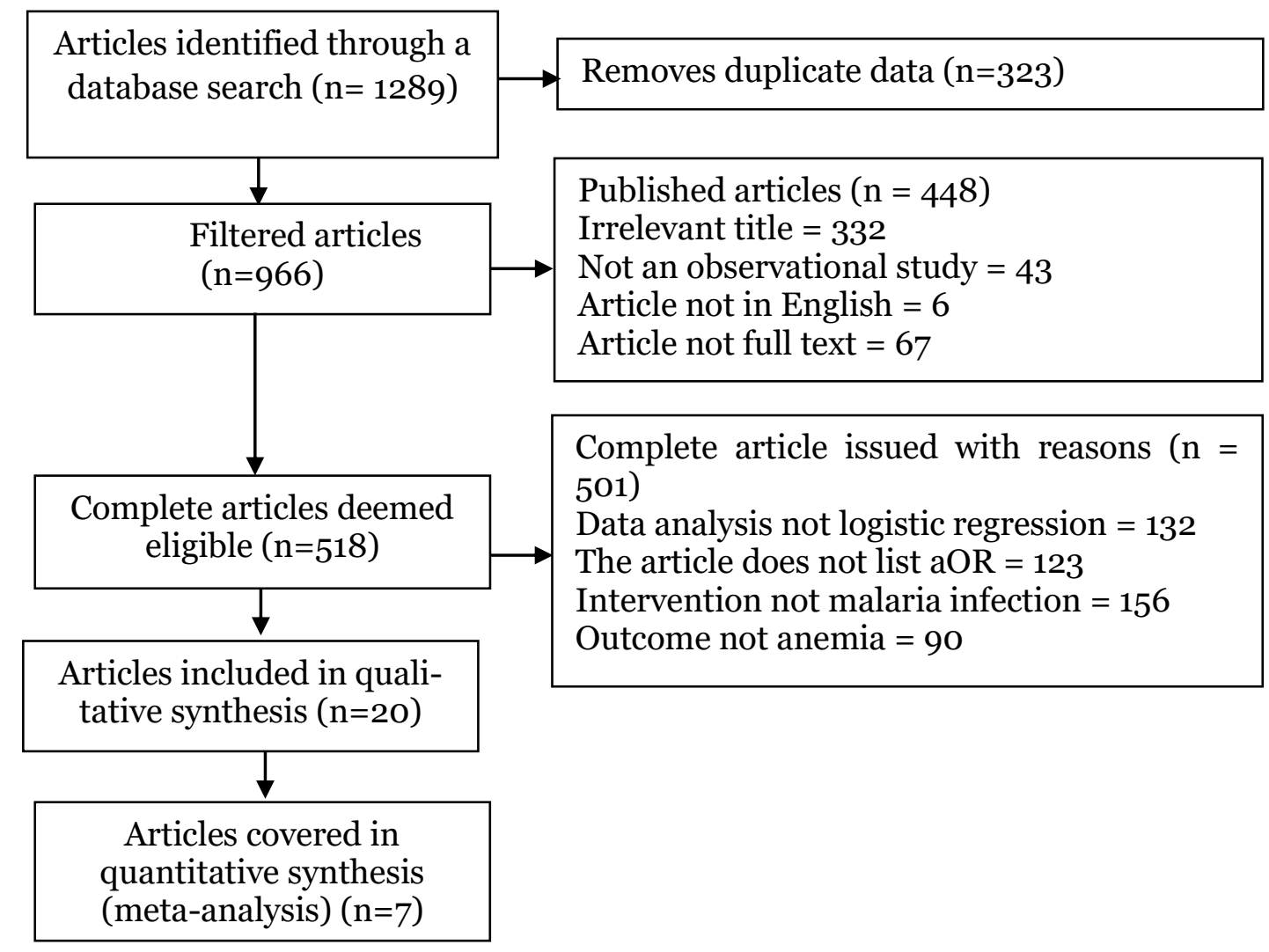

Figure 1. PRISMA flow diagram

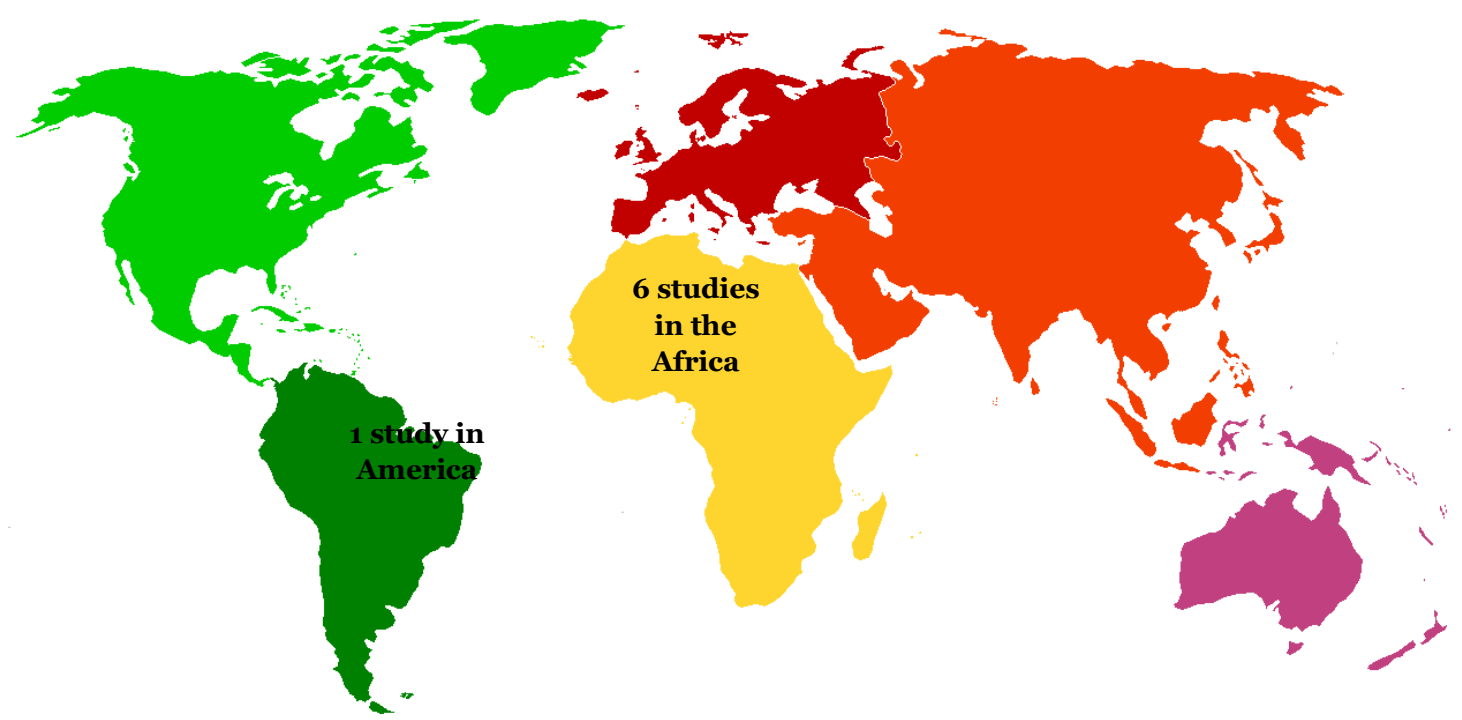

Figure 2. Map of the distribution of the study area on the effect of malaria infection on pregnant women on the incidence of anemia 
Table 1. Assessment of Research Quality using the Critical Appraisal for Cross-sectional Study

\begin{tabular}{|c|c|c|c|c|c|c|c|}
\hline \multirow{2}{*}{ Checklist questions } & \multicolumn{7}{|c|}{$\begin{array}{c}\text { Publication } \\
\text { (Author and Year) }\end{array}$} \\
\hline & $\begin{array}{l}\text { Cisse et al. } \\
(2014)\end{array}$ & $\begin{array}{l}\text { Feleke et } \\
\text { al. }(2016)\end{array}$ & $\begin{array}{l}\text { Chaponda et } \\
\text { al. (2015) }\end{array}$ & $\begin{array}{l}\text { Fondjo et } \\
\text { al. (2020) }\end{array}$ & $\begin{array}{l}\text { Olukosi et } \\
\text { al. (2020) }\end{array}$ & $\begin{array}{l}\text { Mlugu et } \\
\text { al. (2020) }\end{array}$ & $\begin{array}{l}\text { Vásquez et } \\
\text { al. (2020) }\end{array}$ \\
\hline $\begin{array}{l}\text { Does this objective clearly address the } \\
\text { research focus / problem? }\end{array}$ & 1 & 1 & 1 & 1 & 1 & 1 & 1 \\
\hline $\begin{array}{l}\text { Is the cross-sectional research method } \\
\text { suitable for answering research } \\
\text { questions? }\end{array}$ & 1 & 1 & 1 & 1 & 1 & 1 & 1 \\
\hline $\begin{array}{l}\text { Is the method of selecting research } \\
\text { subjects clearly written? }\end{array}$ & 1 & 1 & 1 & 1 & 1 & 1 & 1 \\
\hline $\begin{array}{l}\text { Does the sampling method not } \\
\text { introduce bias (selection)? }\end{array}$ & 1 & 1 & o & 1 & 1 & 1 & 1 \\
\hline $\begin{array}{l}\text { Does the research sample taken } \\
\text { represent the designated population? }\end{array}$ & 1 & 1 & 1 & 1 & 1 & 1 & 1 \\
\hline $\begin{array}{l}\text { Was the sample size based on pre-study } \\
\text { considerations? }\end{array}$ & 1 & o & o & 1 & 1 & o & o \\
\hline Was a satisfactory response achieved? & 1 & 1 & 1 & 1 & 1 & 1 & 1 \\
\hline $\begin{array}{l}\text { Are antenatal depression instruments } \\
\text { valid and reliable? }\end{array}$ & 1 & 1 & 1 & 1 & 1 & 1 & 1 \\
\hline Is statistical significance assessed? & 1 & 1 & 1 & 1 & 1 & 1 & 1 \\
\hline $\begin{array}{l}\text { Are confidence intervals given for the } \\
\text { main outcome? }\end{array}$ & 1 & 1 & 1 & 1 & 1 & 1 & 1 \\
\hline $\begin{array}{l}\text { Have you taken the confounding factor } \\
\text { into account? }\end{array}$ & o & $\mathrm{O}$ & o & o & O & $\mathrm{O}$ & O \\
\hline $\begin{array}{l}\text { Are the results applicable to your } \\
\text { research? }\end{array}$ & 1 & 1 & 1 & 1 & 1 & 1 & 1 \\
\hline Total & 11 & 10 & 9 & 11 & 10 & 10 & 10 \\
\hline
\end{tabular}


Table 2. Descriptions of primary studies included in the meta-analysis

\begin{tabular}{|c|c|c|c|c|c|c|c|c|c|}
\hline $\begin{array}{c}\text { Author } \\
\text { (Year) }\end{array}$ & Country & $\begin{array}{c}\text { Study } \\
\text { Design }\end{array}$ & Sample & $\begin{array}{c}\text { P } \\
\text { Population }\end{array}$ & $\begin{array}{c}\text { I } \\
\text { Intervention }\end{array}$ & $\begin{array}{c}\text { C } \\
\text { Comparison }\end{array}$ & & $\begin{array}{c}\text { O } \\
\text { Itcome }\end{array}$ & \\
\hline $\begin{array}{l}\text { Vásquez et al. } \\
\text { (2020) }\end{array}$ & Colombia & $\begin{array}{l}\text { Cross- } \\
\text { sectional }\end{array}$ & 787 & $\begin{array}{l}\text { Pregnant } \\
\text { mother }\end{array}$ & Malaria & Not malaria & $\begin{array}{l}\text { Pregnant } \\
\text { anemia }\end{array}$ & women & with \\
\hline $\begin{array}{l}\text { Cisse et al. } \\
(2014)\end{array}$ & $\begin{array}{l}\text { Bobo-Dioulasso } \\
\text { (Burkina Faso) }\end{array}$ & $\begin{array}{l}\text { Cross- } \\
\text { sectional }\end{array}$ & 579 & $\begin{array}{l}\text { Pregnant } \\
\text { mother }\end{array}$ & Malaria & Not malaria & $\begin{array}{l}\text { Pregnant } \\
\text { anemia }\end{array}$ & women & with \\
\hline Feleke (2016) & Ethiopia & $\begin{array}{l}\text { Cross- } \\
\text { sectional }\end{array}$ & 1,459 & $\begin{array}{l}\text { Pregnant } \\
\text { mother }\end{array}$ & Malaria & Not malaria & $\begin{array}{l}\text { Pregnant } \\
\text { anemia }\end{array}$ & women & with \\
\hline $\begin{array}{l}\text { Chaponda et } \\
\text { al. (2015) }\end{array}$ & Zambia & $\begin{array}{l}\text { Cross- } \\
\text { sectional }\end{array}$ & 1,086 & $\begin{array}{l}\text { Pregnant } \\
\text { mother }\end{array}$ & Malaria & Not malaria & $\begin{array}{l}\text { Pregnant } \\
\text { anemia }\end{array}$ & women & with \\
\hline $\begin{array}{l}\text { Fondjo et al. } \\
(2020)\end{array}$ & Ghana & $\begin{array}{l}\text { Cross- } \\
\text { sectional }\end{array}$ & 628 & $\begin{array}{l}\text { Pregnant } \\
\text { mother }\end{array}$ & Malaria & Not malaria & $\begin{array}{l}\text { Pregnant } \\
\text { anemia }\end{array}$ & women & with \\
\hline $\begin{array}{l}\text { Olukosi et al. } \\
(2020)\end{array}$ & Nigeria & $\begin{array}{l}\text { Cross- } \\
\text { sectional }\end{array}$ & 113 & $\begin{array}{l}\text { Pregnant } \\
\text { mother }\end{array}$ & Malaria & Not malaria & $\begin{array}{l}\text { Pregnant } \\
\text { anemia }\end{array}$ & women & with \\
\hline $\begin{array}{l}\text { Mlugu et al. } \\
(2020)\end{array}$ & Tanzania & $\begin{array}{l}\text { Cross- } \\
\text { sectional }\end{array}$ & 819 & $\begin{array}{l}\text { Pregnant } \\
\text { mother }\end{array}$ & Malaria & Not malaria & $\begin{array}{l}\text { Pregnant } \\
\text { anemia }\end{array}$ & women & with \\
\hline
\end{tabular}

${ }^{*}$ variables were included in the meta-analysis study 
Nuzula et al./ Meta-Analysis the Effect of Malaria Infection on Anemia in Pregnant Women

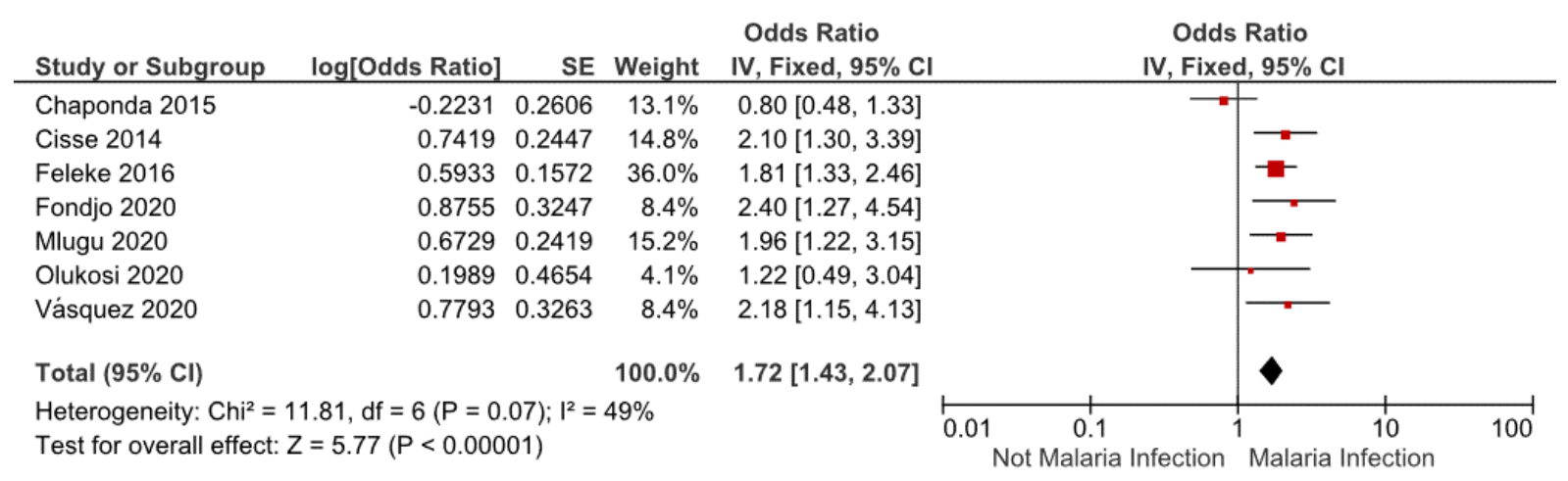

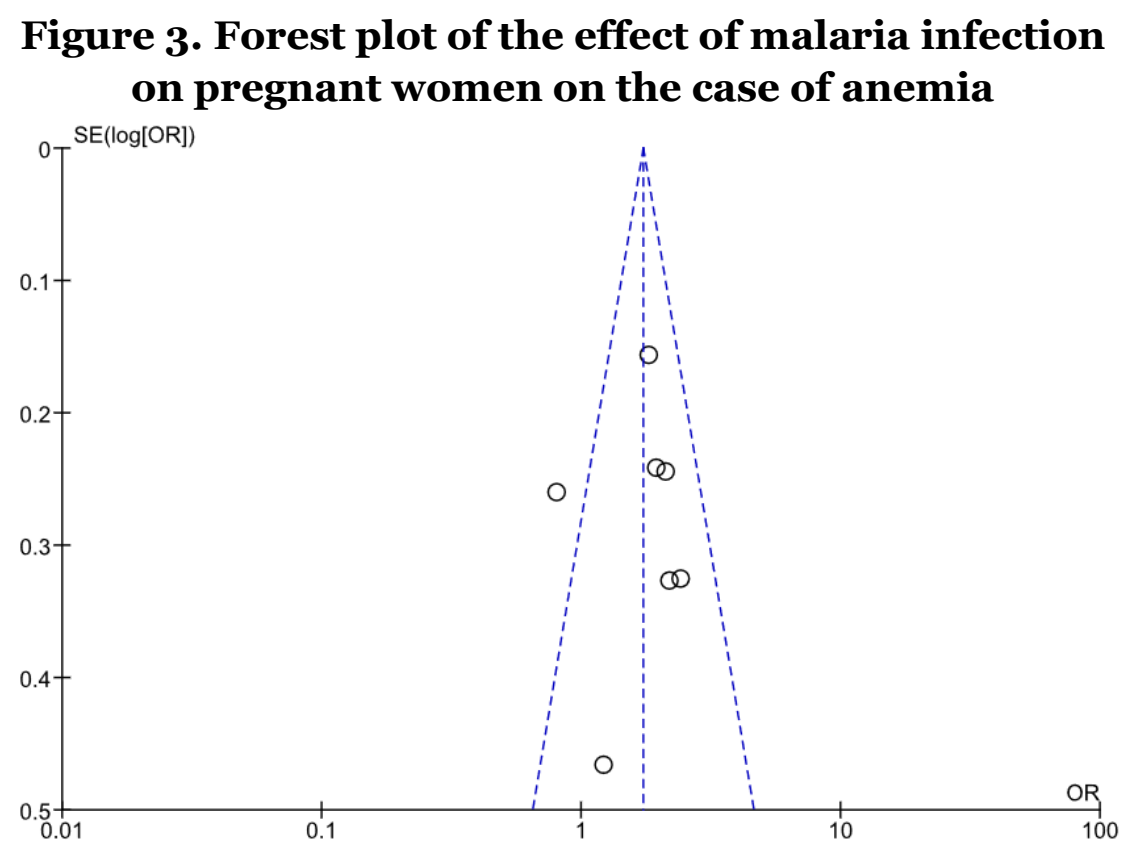

Figure 4. Funnel plot of the effect of malaria infection in pregnant women on the case of anemia

\section{DISCUSSION}

This study is a systematic study and a metaanalysis that raises the theme of the effect of malaria infection in pregnant women on the incidence of anemia. The independent variable analyzed was malaria infection. The dependent variable studied was anemia. The results of primary studies carried out systematic studies and meta-analyzes show an epidemiological study design with a larger sample, different demographic characteristics in both developed and developing countries, thus providing a basis for concluding that malaria infection has a statistical effect on the incidence of anemia in pregnant women. The results of the primary study analysis conducted by systematic review and meta-analysis show that studies that meet the analysis criteria are found in many regions of Africa (BoboDioulasso (Burkina Faso), Ethiopia, Zambia, Ghana, Nigeria, Tanzania) and South America (Columbia).

The analysis was carried out with an observational study design. The results of the meta-analysis of the cross sectional study showed that malaria infection increased the incidence of anemia in pregnant women by 1.72 times compared to 
those who were not infected with malaria (aOR 1.72; 95\% CI 1.43 to $2.07 ; \mathrm{p}<0.001$ ).

In a study by Ouédraogo et al. (2012), it is stated that in line with other studies in sub-Saharan Africa and with recent studies in neighboring areas of Benin, malaria is one of the main factors associated with anemia. Plasmodium falciparum directly destroys erythrocytes, but more complex phenomena are also involved, such as inhibition of erythropoiesis by malaria pigments and malaria-induced pro-inflammatory mediators. Malaria is mainly found in climatic factors such as temperature, humidity and rainfall. Malaria spreads in tropical and subtropical areas, where Anopheles can survive and breed, and Plasmodium can complete its growth cycle in mosquitoes. Usually cases of malaria occur in warmer areas near the equator. The highest rates of transmission are found in the Sahara Desert in South Africa and parts of Oceania, such as Papua New Guinea (CDC, 2020)..

The analysis was carried out with an observational study design. The results of the meta-analysis of the cross sectional study showed that malaria infection increased the incidence of anemia in pregnant women by 1.72 times compared to those who were not infected with malaria (aOR 1.72; 95\% CI 1.43 to 2.07; $\mathrm{p}<0.001$ ).

In line with the results of research conducted by Fondjo (2020), among pregnant women with anemia, among them suffer from malaria. Regression analysis of the studies revealed that malaria increased the risk of anemia by up to twofold among the population. In Bauserman et al. (2019) Anemia is one of the most common symptoms of malaria in pregnancy. Plasmodium causes anemia through hemolysis, increased clearance of the spleen from erythrocytes, and decreased red blood cell production. The clinical effects of malaria on pregnant women vary from asympto- matic to anemia and death. Women living in areas with low malaria transmission with lower degrees of acquired immunity are more likely to experience complications such as kidney failure, pulmonary edema, and cerebral malaria.

Alvarez (2014) also states that pregnancy-related malaria, defined as peripheral or placental infection by Plasmodium, is emerging as a major public health problem due to its significant adverse health effects on the mother and the fetus.

The findings about the overall prevalence of anemia among pregnant women in this study were higher than those reported from the Sunyani Municipality of Ghana, a factor strongly associated with anemia in this study, namely primagravida, gestational age at the first ANC visit, had a history of malaria parasite-mia (Dosoo et al., 2020).

Pregnancy with malaria is associated with the incidence of anemia, malaria anemia is caused by a combination of bone marrow dysfunction and damage to infected and uninfected erythrocytes. In pregnancy, this is often caused by micronutrient deficiencies (eg iron and folic acid), HIV infection, hookworm infection, or chronic inflammation (Rogerson et al., 2007).

\section{AUTHOR CONTRIBUTION}

Firdausi Nuzula is the principal researcher who selects topics, searches and collects research data. Setyo Sri Rahardjo and Bhisma Murti played a role in analyzing data and reviewing research documents

\section{CONFLICT OF INTEREST}

There is no conflict of interest in this study.

\section{FUNDING AND SPONSORSHIP}

This study is self-funded. 


\section{ACKNOWLEDGEMENT}

We are very grateful to the database providers Google Scholar, PubMed, and Science Direct.

\section{REFERENCE}

Alvarez MV, Ouédraogo S, Accrombessi M, Cot $M$ (2018). High folate levels are not associated with increased malaria risk but with reduced anaemia rates in the context of high-dosed folate supplements and intermittent preventive treatment against malaria in pregnancy with sulphadoxine-pyrimethamine in Benin. Trop Med Int Health. 23 (6): 582-588. https://doi.org/10.1111/tmi.13064.

Anulus A, Murti B, Prasetya H (2019). Risk factors of HIV among male military personnels: A Meta Analysis. J Health Promot and Behav. 4(3): 178-188. doi: 10.26911/thejhpb.2019.04.03.03.

Bauserman M, Conroy AL, North K, Patterson J, Bose C, Meshnick S (2019). An overview of malaria in pregnancy. Semin Perinatol. 43(5): 282-290. https://doi.org/10.1053/j.semperi.2019.03.018.

Budiyanto A, Wuriastuti T (2017). Faktor yang berhubungan dengan kejadian malaria pada ibu hamil di Indonesia (Factors associated with the incidence of Malaria in Pregnant Women in Indonesia). Media Penelitian dan Pengembangan Kesehatan. 27(1): 2530. https://doi.org/10.22435/mpk.v27i1.5494.25-30.

CDC (2020). Parasites - Malaria. Retrieved from https://www.cdc.gov/parasites/malaria/index.html.

CEBMa (2014). Critical Appraisal. Amsterdam: Center for Evidence Based Management.

Chaponda EB, Chandramohan D, Michelo C, Mharakurwa S, Chipeta J, Chico
RM (2015). High burden of malaria infection in pregnant women in a rural district of Zambia: A crosssectional study. Malaria Journal. 14(1): 1-12. https://doi.org/10.1186/s12936-015-0866-1.

Cisse M, Sangare I, Lougue G, Bamba S, Bayane D, Guiguemde RT (2014). Prevalence and risk factors for Plasmodium falciparum malaria in pregnant women attending antenatal clinic in Bobo-Dioulasso (Burkina Faso). BMC Infectious Diseases. 14(1): 1-7. https://doi.org/10.1186/s12879-014-0631$\mathrm{z}$.

Corrêa G, Das M, Kovelamudi R, Jaladi N, Pignon C, Vysyaraju K, Yedla U, et al. (2017). High burden of malaria and anemia among tribal pregnant women in a chronic conflict corridor in India. Confl Health. 11 (1): 1-9. https://doi.org/10.1186/s13031-017-0113-1.

Feleke BE (2016). Maternal HIV status affects the infant hemoglobin level: A comparative cross-sectional study. Medicine (United States). 95(31): 1-5. https://doi.org/10.1097/MD.000000 0000004372.

Fondjo LA, Addai-Mensah O, AnnaniAkollor ME, Quarshie JT, Boateng AA, Assafuah SE, Owiredu EW (2020). A multicenter study of the prevalence and risk factors of malaria and anemia among pregnant women at first antenatal care visit in Ghana. PLoS ONE. 15 (8): e0238077. https://doi.org/10.1371/journal.pone.0238077.

Kementerian Kesehatan RI (2014). Profil Kesehatan Indonesia Tahun 2013. Jakarta: Kementerian Kesehatan RI. https://doi.org/10.1017/CBO9781107 415324.004. 
Kementerian Kesehatan RI (2019). Profil Kesehatan Indonesia 2019. Kementerian Kesehatan RI. 8 (9): 1-58.

Mlugu EM, Minzi O, Kamuhabwa AAR, Aklillu E (2020). Prevalence and correlates of asymptomatic malaria and anemia on first antenatal care visit among pregnant women in Southeast, Tanzania. International Journal of Environmental Research and Public Health. 17(9). https://doi.org/10.3390/ijerph17093123.

Murti B (2018). Prinsip dan metode riset epidemiologi (The Principles and Research Methods of Epidemiology). $5^{\text {th }}$ edn. Surakarta: Universitas Sebelas Maret.

Olukosi AY, Olakiigbe A, Ajibaye O, Orok BA, Aina OO, Akindele SK, Akinyele $\mathrm{OO}$ et al. (2020). Socio-economic behavioural indicators of falciparum malaria parasitaemia and moderate to severe anaemia among pregnant women attending antenatal clinics in Lagos, Southwest Nigeria. Malaria Journal. 19(1): 1-11. https://doi.org/10.1186/s12936-020-03462-8.

Rogerson SJ, Desai M, Mayor A, Sicuri E, Taylor SM, van Eijk AM (2018).
Burden, pathology, and costs of malaria in pregnancy: new developments for an old problem. Lancet Infect Dis. 18(4): e107-e118. https://doi.org/10.1016/S14733099(18)30066-5.

Vásquez AM, Zuluaga-Idárraga L, Arboleda M, Usuga LY, Gallego-Marin C, Lasso A, Carbal L, et al. (2020). Malaria in pregnancy in endemic regions of Colombia: High frequency of asymptomatic and peri-urban infections in pregnant women with malaria. Infect Dis Obstet Gynecol. https://doi.org/10.1155/2020/2750258.

Wabula WM, Suryadhi NT, Ani LS (2014). Hubungan antara konsumsi tablet besi dan infeksi malaria dengan anemia pada ibu hamil di Kota Ambon (Relationship between iron tablet consumption and malaria infection with anemia in pregnant women in Ambon City). Public health prev. med. arch. 2(2): 131. https://doi.org/10.15562/phpma.v2i2.139.

WHO (2019). World malaria report 2019. Retrieved from: https://www.who.int/newsroom/fact-sheets/detail/malaria. 